\title{
Nuclear Migration: An Indicator of Plant Salinity Tolerance in vitro
}

\section{OPEN ACCESS}

Edited by: Alma Balestrazzi,

University of Pavia, Italy

Reviewed by:

Photini V. Mylona,

Hellenic Agricultural Organisation (HAO), Greece

Ahmad Arzani,

Isfahan University of Technology, Iran

*Correspondence:

Hilary J. Rogers

RogersHJ@cardiff.ac.uk

Sergio J. Ochatt

Sergio.ochatt@inra.fr

tPresent address:

Adel M. Elmaghrabi,

Plant Tissue Culture Department,

Biotechnology Research Center

(BTRC), Tripoli, Libya

Specialty section:

This article was submitted to Plant Breeding,

a section of the journal

Frontiers in Plant Science

Received: 05 February 2019

Accepted: 29 May 2019

Published: 12 June 2019

Citation:

Elmaghrabi AM, Francis $D$, Rogers HJ and Ochatt SJ (2019)

Nuclear Migration: An Indicator

of Plant Salinity Tolerance in vitro.

Front. Plant Sci. 10:783.

doi: $10.3389 /$ fpls.2019.00783

\author{
Adel M. Elmaghrabi1,2t, Dennis Francis ${ }^{1}$, Hilary J. Rogers ${ }^{* *}$ and Sergio J. Ochatt ${ }^{2 *}$ \\ 'School of Biosciences, Cardiff University, Cardiff, United Kingdom, ${ }^{2}$ Agroécologie, AgroSup Dijon, INRA, Université \\ Bourgogne Franche-Comté, Dijon, France
}

In order to understand the mechanisms underlying acquisition of tolerance to salinity, we recently produced callus tissues of tobacco and Medicago truncatula resistant to $\mathrm{NaCl}$ induced salt stress following application of a step-up recurrent selection method. The effects of salinity on cell size are known, but those on cell morphometry including cell and nuclear surface area and position of nuclei within salt stress resistant cells were never studied before. This work fills that gap, using suspension cultured cells of $M$. truncatula A17 initiated from callus, and Nicotiana tabacum BY-2 cell line resistant to increasing $\mathrm{NaCl}$ concentrations up to $150 \mathrm{mM} \mathrm{NaCl}$. The surface area of salinity resistant cells of M. truncatula A17 and N. tabacum BY2 and their nuclei, produced by step-up recurrent selection, were reduced, and cells elongated as $\mathrm{NaCl}$ increased, but these parameters proved to be unreliable in explaining cell survival and growth at high $\mathrm{NaCl}$. Conversely, nuclei of resistant cells migrated from the center to the periphery of the cytoplasm close to the walls. Nuclear marginalization was for the first time observed as a result of salt stress in plant cells, and could be a novel helpful morphological marker of acquisition of salinity tolerance.

\footnotetext{
Keywords: abiotic stress, cell morphometry, cell suspensions, Medicago truncatula, Nicotiana tabacum, nucleus position, salinity tolerance
}

\section{INTRODUCTION}

Increased soil salinity is a world-wide problem, hence there is a need to develop more salinityresistant crop cultivars (Ochatt, 2015). The mechanisms of plant salt tolerance in vivo have been investigated at the molecular, cellular, and whole plant levels (Munns and Tester, 2008). In vitro selection for salt tolerance has focused on cellular (Davenport et al., 2003) and genetic (Elmaghrabi et al., 2013) mechanisms involved in salt tolerance using selected $\mathrm{NaCl}$-tolerant cell lines, while gene transfer has also been successfully exploited very recently to generate salt (Confalonieri et al., 2019) and water stress (Confalonieri et al., 2014; Alcântara et al., 2015; Duque et al., 2016) tolerance in M. truncatula. Alternative methods to exploit in vitro stress to characterize the biology and genetic diversity of early stage seedling growth (Parida and Das, 2005; Elmaghrabi et al., 2013), as well as effects of salinity stress on plant morphology, have also been extensively studied (Parida and Das, 2005; Claeys et al., 2014; Golkar et al., 2017; Negrão et al., 2017). However, only effects of salinity on cell size have been examined to date (Kurth et al., 1986) while those on cell morphometry have not.

Nuclear positioning is important during cell division, mediated by the three cytoskeletal filament systems, F-actin, intermediate filaments (IF), and microtubules (Ingber, 2003). In a recent review, Gundersen and Worman (2013) examined the sparse knowledge and understanding of the reasons and effects of cell movement and of the position of their nuclei within the cytoplasm. Given that 
nuclear positioning has been reported to reflect an interference with the proteins involved in nuclear movement (Maniotis et al., 1997; Folker et al., 2011), they hypothesized that this may then inhibit a number of cellular activities. These include an effect on the organization and mechanical properties of the cytoplasm with a concomitant impact on cytoplasmic signaling and on the accessibility of the nucleus to the associated signaling pathways (Dahl et al., 2004; Gundersen and Worman, 2013). However, to our knowledge, this hypothesis that nuclear movement may regulate cellular signaling pathways and responses to stress (Gundersen and Worman, 2013) has never been directly tested to date, be it with animal or plant cells.

Recently we developed a step-up selection method in M. truncatula, for obtaining embryogenic calli under increasing salt stress. Within 5 months, different developmental patterns of callus varying between embryogenic to a non-regenerative condition were observed, correlated with a differential nuclear DNA content and biochemical profile (Elmaghrabi and Ochatt, 2006; Elmaghrabi et al., 2013). Callus growth was significantly impaired at $\geq 100 \mathrm{mM} \mathrm{NaCl}$ but green callus was observed up to $100-150 \mathrm{mM} \mathrm{NaCl}$, coincident with healthy growth despite the high salinity. However, 250 and $350 \mathrm{mM} \mathrm{NaCl}$ were lethal to most cells, and only small clusters of cells survived. To assess how this step-up approach affected cellular morphology, it was adapted and applied to M. truncatula and N. tabacum cells in suspension cultures. As well as monitoring cell and nuclear area, we have now filled the gap in morphometric analysis showing here that nuclear positioning is affected by the $\mathrm{NaCl}$ treatments.

\section{MATERIALS AND METHODS}

Calli from leaves of Medicago truncatula cv. Jemalong line A17 were subcultured monthly on MS medium (Murashige and Skoog, 1962) supplemented with $2.0 \mathrm{mg} / \mathrm{l}$ NAA (1naphthaleneacetic acid), $0.5 \mathrm{mg} / \mathrm{l}$ BAP (6-benzylaminopurine) and $3 \%(\mathrm{w} / \mathrm{v})$ sucrose; $\mathrm{pH}$ was adjusted to 5.8 before addition of $0.9 \%(\mathrm{w} / \mathrm{v})$ agar (MANA medium). Media were autoclaved for $20 \mathrm{~min}$ at $121^{\circ} \mathrm{C} / 1$ par. Cultures were kept at $24 / 22^{\circ} \mathrm{C}$ with a $16 / 8 \mathrm{~h}$ (light/dark) photoperiod of $90 \mu \mathrm{E} \mathrm{m} \mathrm{m}^{-2} \mathrm{~s}^{-1}$ from warm white fluorescent tubes, as reported previously (Elmaghrabi and Ochatt, 2006; Elmaghrabi et al., 2013, 2017).

After 5 months of callus induction on MANA medium, $0.5 \mathrm{~g}$ fresh weight pieces of callus were transferred into $250 \mathrm{ml}$ Erlenmeyer flasks containing $100 \mathrm{ml}$ of BY-2 liquid medium and used to establish cell suspensions. BY-2 liquid medium (Nagata et al., 1992) consists of MS (Murashige and Skoog, 1962) medium modified with $0.2 \mathrm{mg} / \mathrm{l}$ 2,4D, $1 \mathrm{mg} / \mathrm{l}$ Thiamine- $\mathrm{HCl}$,

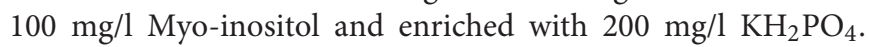
Cell suspensions were sub cultured every 2 weeks. After four subcultures, once proliferation of suspension cells stabilized, cells were sub cultured into the same medium with a low concentration of $\mathrm{NaCl}(0,35,50$, and $70 \mathrm{mM})$ for gradual acclimation to salt-stress. One month later, these concentrations were changed to $0,50,100$, and $150 \mathrm{mM} \mathrm{NaCl}$ and suspension cultures were maintained as above. Tobacco (Nicotiana tabacum) BY-2 cell cultures were analyzed as a comparison to the
M. truncatula suspension cultures, by adding the same $\mathrm{NaCl}$ concentrations to BY-2 liquid medium. Cell suspension cultures of both species were shaken $(130 \mathrm{rpm})$ and were sub cultured every 14 days (Elmaghrabi and Ochatt, 2006).

The viability of the cell suspension cultures was tested by dual propidium iodide (PI) and flouroscein diacetate (FDA) viability staining. The dual stain contained PI $\left(0.24 \mathrm{mg} \mathrm{ml}^{-1}\right)$ and FDA $(0.04 \%)$ and sucrose (w/v, 2\%). The cell suspension $(75 \mu \mathrm{l})$ was added to $75 \mu \mathrm{l}$ of dual staining solution and incubated on ice for $20 \mathrm{~min}$. Percentage cell mortality was counted using an Olympus $\mathrm{BH} 2$ fluorescent microscope at $20 \times$ magnification. Approximately 300 cells were scored as either living (green) or dead (red). Culture viability was also assessed by measuring cell density using a spectrophotometer at $600 \mathrm{~nm}$ and visually by increasing density of the culture during the 2 week subculture period.

Hoechst staining $\left(1 \mu \mathrm{L}\right.$ of a $10 \mathrm{mg} \mathrm{ml}^{-1}$ stock of Bisbenzimide $\mathrm{H}, 2 \mu \mathrm{L}$ Triton $\mathrm{X}-100$ and $97 \mu \mathrm{L}$ sterile distilled $\mathrm{H}_{2} \mathrm{O}$ ) was used to assess cell morphology, using an Olympus $\mathrm{BH}$ 2 compound microscope equipped with UV epi-fluorescence. Following 60 days of acclimation to increased salinity, cell and nuclear size were measured using Sigmascan-pro (objective: DPlan Apo $20 \mathrm{UV}, 0.70,160 / 0.17)$. Position of nuclei within cells was determined using ArchimedPro and Histolab software (Microvision, France) by six measurements $60^{\circ}$ apart for each cell, $n=13-19$ cells (Supplementary Figure 1).

Data were analyzed using $\mathrm{R}$ software ( $\mathrm{R}$ version 3.3.2, Foundation for Statistical Computing). ANOVA tests followed by a Tukey's test, or non-parametric Kruskal-Wallis followed by a Dunn's test were applied to determine differences across multiple samples.

\section{RESULTS}

In $M$. truncatula cell suspensions, the initial trend was an increase in cell and nuclear area following 60 days exposure to $50 \mathrm{mM}$ $\mathrm{NaCl}$ although these increases were not significant $(P>0.05)$. Likewise, in the tobacco cultures cell area remained stable up to $50 \mathrm{mM} \mathrm{NaCl}$, although nuclear area was already significantly lower than the control (Figure 1). When the $\mathrm{NaCl}$ concentration was raised further, to 100 or $150 \mathrm{mM}$, both nuclear and cell area decreased in both species, perhaps as a function of plasmolysis. Cell area was significantly lower than the control at $150 \mathrm{mM}$ in both species, and nuclear area was significantly lower than the control in both the 100 and $150 \mathrm{mM} \mathrm{NaCl}$ treatments $(P<0.05$; Figure 1). This decline in cell and nuclear size across treatments, despite the presence of viable cells even at the highest $\mathrm{NaCl}$ concentration (Supplementary Table 1), and the lack of response at $50 \mathrm{mM} \mathrm{NaCl}$ suggests that these traits are not a reliable criterion to assess cell growth of $M$. truncatula or tobacco in response to $\mathrm{NaCl}$ stress over a longer period. Similar trends were noted for both cell and nuclear area when suspensions were cultured under the same conditions for up to 4 months (Supplementary Figures 2, 3). Moreover, they showed the opposite trend to those observed for osmotic stress-resistant cells of $M$. truncatula where osmotic stress provoked an increase 

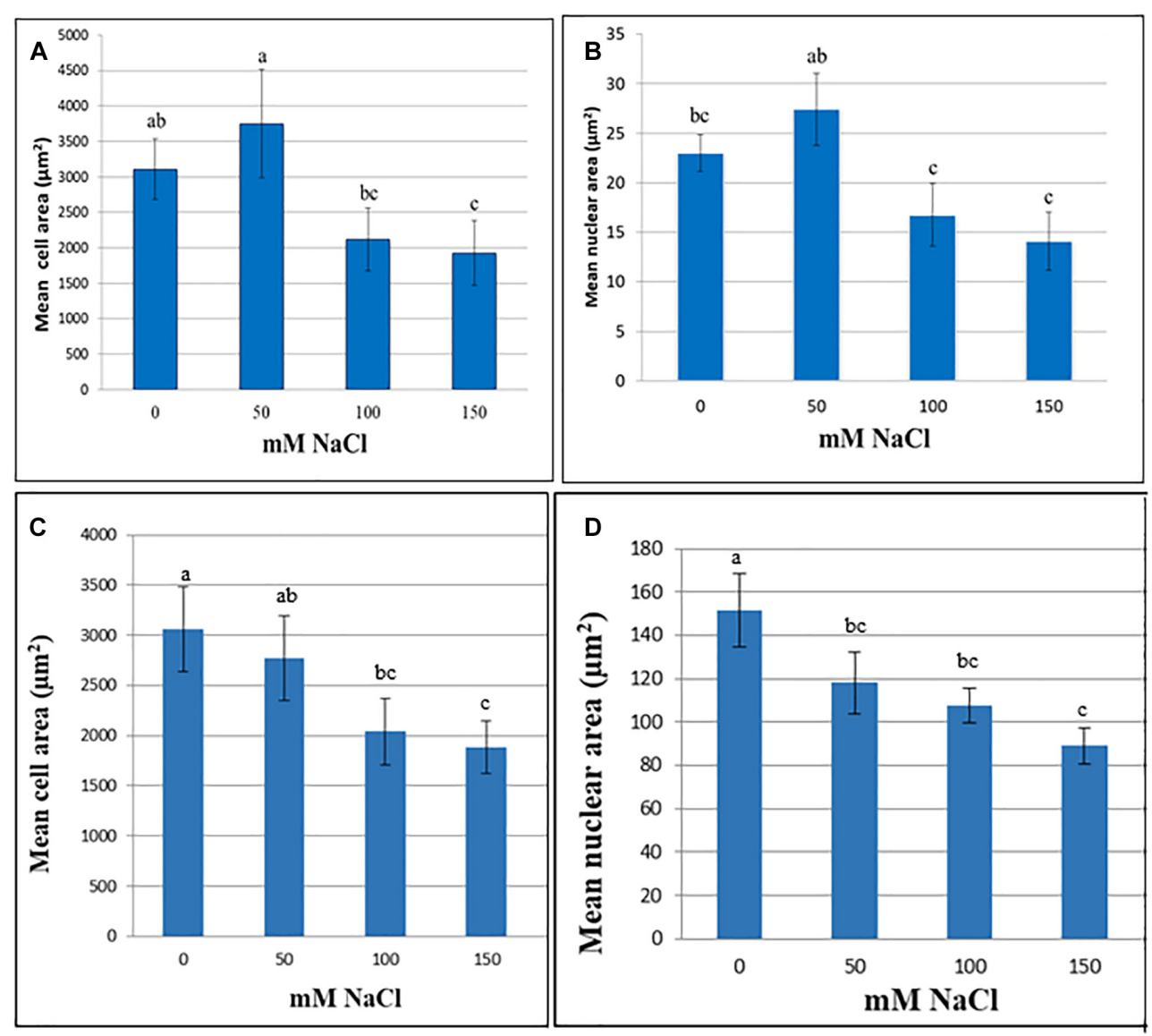

FIGURE 1 | Cell $(\mathbf{A}, \mathbf{C})$ and nuclear (B,D) area $\left(\mu \mathrm{m}^{2}\right)$ at various $\mathrm{NaCl}$ concentrations of cell suspensions of $M$. truncatula $\mathbf{( A , B )}$ and $N$. tabacum $(\mathbf{C}, \mathbf{D})$ measured at 60 and 8 days, respectively, following the start of treatment (mean $\pm \mathrm{SE}, n=12$ ). Letters above bars denote significant differences in area between $\mathrm{NaCl}$ concentration datasets $(P<0.05)$.

in cell and nuclear area concomitant with endoreduplication (Elmaghrabi et al., 2017).

We observed mitoses in the M. truncatula cell suspensions established from callus for monitoring cellular behavior under salt stress $(0,50,100$, or $150 \mathrm{mM} \mathrm{NaCl}$; Figure 2A). Our aim was to identify a characteristic cellular/nuclear phenotype as a consistent marker of fast growing or salt tolerant callus, for use as a diagnostic criterion of acquisition of in vitro salt tolerance in $M$. truncatula, as recently observed under osmotic stress (Elmaghrabi et al., 2017).

Interestingly, subjecting the cell suspension cultures to the 50, 100 , and $150 \mathrm{mM} \mathrm{NaCl}$ treatments for 2 months consistently resulted in the migration of nuclei from the center toward the periphery of cells (Figure 2C and Supplementary Table 2). To test whether this was a distinctive feature of $M$. truncatula or a more general response to salt stress by plant cells, the tobacco cells were also analyzed, and the same effect was seen (Figure 2B). This repositioning was never observed for the control cells of either species studied when grown under stress-free conditions, where the nucleus maintained a central position within the cytoplasm, equidistant to the wall (Figures 2A,B, first panel). It is also noteworthy in this respect, that these observations were undertaken on cell suspensions that had undergone already the repeated cycles with and without $\mathrm{NaCl}$ during the step-up protocol through which they were produced, which would suggest that the phenomenon of nucleus repositioning is correlated to the acquisition of salt tolerance.

\section{DISCUSSION}

In addition to being a model species, $M$. truncatula (barrel medic) can fix atmospheric nitrogen, has high protein content (Young and Udvardi, 2009) and includes cultivars with relatively high salinity tolerance (Merchan et al., 2003). We developed a method for induction of new accessions of $M$. truncatula tolerant to salinity induced by $\mathrm{NaCl}$ (Elmaghrabi et al., 2013) and also to osmotic stress provoked by PEG 6000 (Elmaghrabi et al., 2017), in both cases through in vitro selection via a step-up recurrent strategy. A gradual exposure to successively higher $\mathrm{NaCl}$ concentrations has led to long-term acclimation of cells to salinity in other plant species, and embryogenic and organogenic callus produced by this method have enabled selection of salt resistant cultures (Miki et al., 2001; Merchan et al., 2003). Long-term 

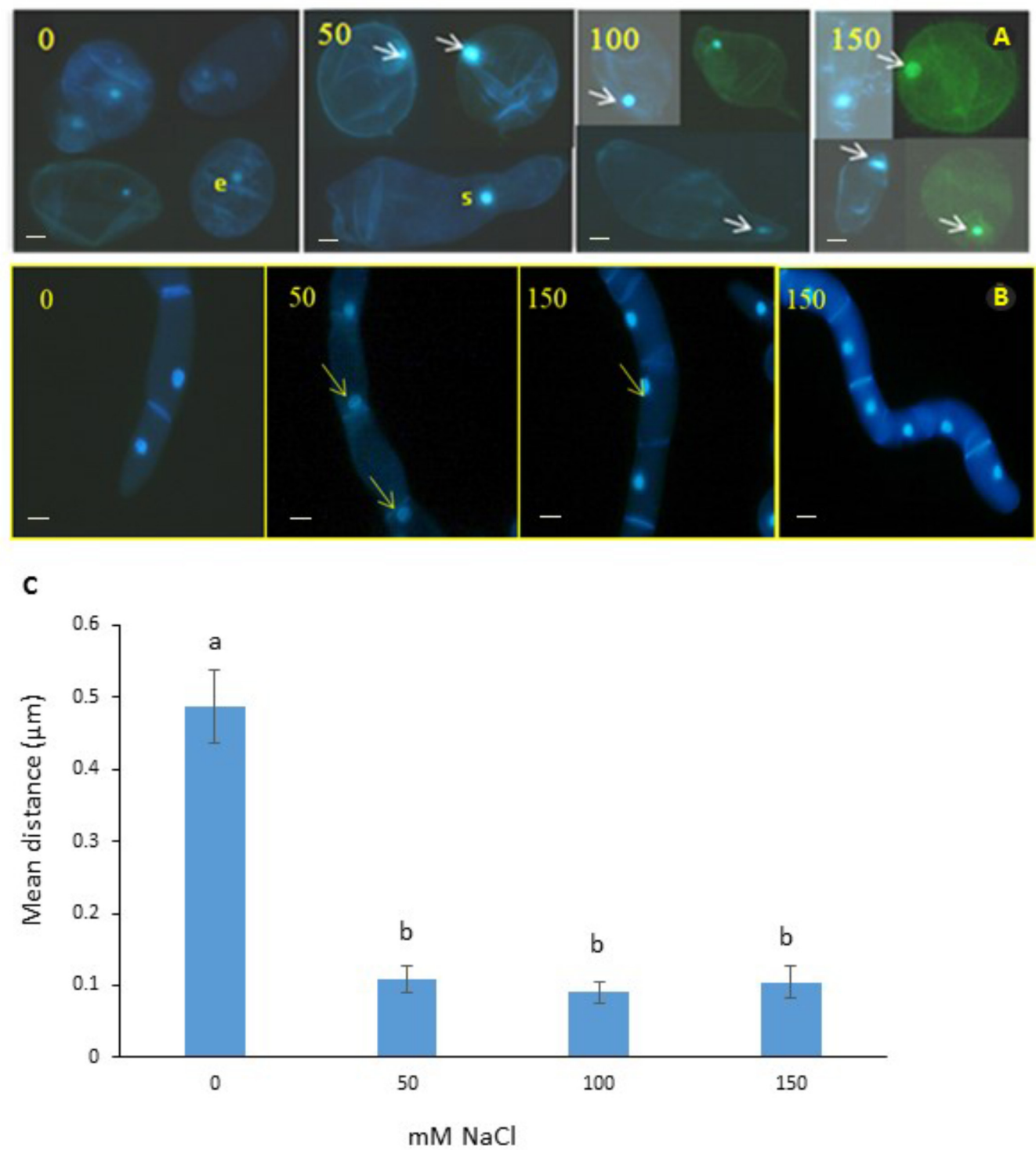

FIGURE 2 | Nuclear positioning in cell suspensions of $M$. truncatula (A) and N. tabacum (B) at different concentrations of salt (mM NaCl). Arrows show migration of the nuclei to the cell wall and elongation of cytoplasm in the 50 and $100 \mathrm{mM} \mathrm{NaCl}$ treatments. It is unlikely that this cellular phenotype has embryogenic potential; e, denotes a small cell with a small nucleus in the $0 \mathrm{mM} \mathrm{NaCl}$ treatment that might have embryogenic potential; and s, indicates septum forming along the presumptive cell plate of a cell undergoing cytokinesis. Bar scale $=20 \mu \mathrm{m}$. (C) Position of nucleus in $\mathrm{M}$. truncatula cells exposed to NaCl (0-150 mM). Means of six measurements from nuclear envelope to cell wall for each cell + SE; $n=13-19$ cells (see Supplementary Figure 1). Different letters indicate significantly different means (Kruskal Wallis followed by a Dunn's test, $P<0.05$ ).

culture under salt stress conditions may simultaneously induce physiological adaptation in cells (Naliwajski and Skłodowska, 2014) and the generation of acclimated and truly tolerant somaclones (Arzani, 2008), which are then capable of growth at $\mathrm{NaCl}$ concentrations that are lethal to non-acclimated ones. In this respect, the continuous assessment of cell viability with time in culture and following our step-up recurrent strategy resulted in a gradual enrichment in truly tolerant cells in the population selected under $\mathrm{NaCl}$ stress and the concomitant death of those cells that were only physiologically adapted to the stress imposed (Elmaghrabi et al., 2013).
Here using cell suspension cultures, we explored how exposure to increasing salinity over long culture periods affected cell morphology, and demonstrate that an alteration of nuclear position was more sensitive to low $\mathrm{NaCl}$ concentrations than changes in nuclear or cell area. Here we only assessed a single variety of $M$. truncatula, and it will be interesting for future studies to assess different genotypes and species of Medicago known for their differential responses to salinity stress, as shown with M. sativa (Ehsanpour and Fatahian, 2003; Quan et al., 2016). However, nuclear repositioning in response to $\mathrm{NaCl}$ was shown here to be consistent across two very different species, 
M. truncatula and $N$. tabacum suggesting that it may be a widespread plant cellular response.

Understanding of the cellular significance of nuclear position within cells in terms of both their metabolism and physiology is still in its infancy, and all studies on the movement of cells and positioning of their nuclei thus far have been restricted to human and animal cells (Gundersen and Worman, 2013). Among them, in cancerous cells, nuclear positioning was shown to alter their ability to respond to the pathways regulating transcription and mRNA transport and localization (Calvo et al., 2010). It was also speculated that the distance the nuclei traveled depended on various cytoplasmic stimulatory and inhibitory factors, whereby their change of position relative to the origin of an external signal may modulate the nuclear response particularly when signaling is asymmetrical. However, only one study in zebrafish has examined the relationship between nuclear position and asymmetrical signaling (Del Bene et al., 2008). Our results with salt-tolerant plant cells are in line with the studies above. In zebrafish gradients of external stress-inducing factors during development, resulted in a repositioning of the nucleus within the cytoplasm so that its responsiveness to stress might be improved by replacing the nucleus in the close proximity to the stress signal.

Such migration of nuclei from the center of cells toward the outside is a type of perturbation not shown before in plant cells to our knowledge, and appears to be a major effect of salt at the cellular level perhaps related to negative growth responses to the increasing internal concentrations of $\mathrm{NaCl}$ of cells in culture. Nuclear migration will be concomitant with the typical cell responses to osmotic stress, including changes in cell wall thickness, vacuole volume and plastid rearrangements as observed in Arabidopsis (Gobert et al., 2007), but also in the surface area of cells and their nuclei as recently reported in osmotic stress resistant cells of $M$. truncatula (Elmaghrabi et al., 2017).

Exposure to high salt stress can induce rapid nuclear deformation (Katsuhara and Kawasaki, 1996) leading to programmed cell death. Moreover, growth of barley at $192 \mathrm{mM}$ $\mathrm{NaCl}$ resulted in chromatin condensation (Werker et al., 1983). Nuclear marginalization has also been associated with cell death (O'Brien et al., 1998), suggesting that some of the cells under salt stress in this study are preparing to undergo cell death. On the other hand, M. truncatula cell suspensions were shown to respond to stress like whole plants (Elmaghrabi et al., 2013; Araújo et al., 2016) and, in this context, nuclear marginalization as observed would be a part of an eustress cellular mechanism to cope with the induced stress. In this respect, eustress is an

\section{REFERENCES}

Alcântara, A., Morgado, R. S., Silvestre, S., Marques da Silva, J., Berbnardes da Silva, A., Fevereiro, P., et al. (2015). A method to identify early-stage transgenic Medicago truncatula with improved physiological response to water deficit. Plant Cell Tiss. Organ Cult. 122, 605-616. doi: 10.1007/s11240-0150793-4

Araújo, S., Balestrazzi, A., Faè, M., Morano, M., Carbonera, D., and Macovei, A. (2016). MtTdp2 $\alpha$-overexpression boosts the growth phase of Medicago activating, stimulating stress, which is a positive element in plant development, and is also referred to as good stress or constructive stress that can promote plant defense secondary metabolisms for improving tolerance to further stress (Kranner et al., 2010; Hideg et al., 2013).

\section{CONCLUSION}

In conclusion, cell and nuclear size decreased at high $\mathrm{NaCl}$, consistent with signs of plasmolysis, but were not useful traits in explaining cell survival and growth at high $\mathrm{NaCl}$ concentrations. Conversely, nuclear marginalization was for the first time observed as a result of salt stress in plant cells, and could be a novel and helpful morphological indicator for acquisition of salinity tolerance. Importantly, our results strongly suggest that the repositioning of the nucleus within the cytoplasm is not passive nor random. Indeed, it results from the onset under stress of a mechanism that may be a common response across eukaryotes.

\section{AUTHOR CONTRIBUTIONS}

DF, HR, and SO designed the project and experiments. AE performed the experiments. SO and HR wrote and revised the manuscript. All authors analyzed the data, read, and approved the manuscript.

\section{FUNDING}

In this work, AE was financially supported by the Biotechnology Research Center, Tripoli.

\section{ACKNOWLEDGMENTS}

We thank Catherine Conreux and Mike O'Reilly for their technical assistance.

\section{SUPPLEMENTARY MATERIAL}

The Supplementary Material for this article can be found online at: https://www.frontiersin.org/articles/10.3389/fpls.2019.00783/ full\#supplementary-material

truncatula cell suspension and increases the expression of key genes involved in the antioxidant response and genome stability. Plant Cell Tiss. Organ Cult. 127, 675-680. doi: 10.1007/s11240-016-1075-5

Arzani, A. (2008). Improving salinity tolerance in crop plants: a biotechnological view. In Vitro Cell Dev. Biol. Plant 44, 373-383. doi: 10.3389/fpls.2016. 01336

Calvo, F., Agudo-Ibáñez, L., and Crespo, P. (2010). The Ras-ERK pathway: understanding site-specific signaling provides hope of new anti-tumor therapies. Bioessays 32, 412-421. doi: 10.1002/bies.200900155 
Claeys, H., Van Landeghem, S., Dubois, M., Maleux, K., and Inzé, D. (2014). What is stress? Dose-response effects in commonly used in vitro stress assays. Plant Physiol. 165, 519-527. doi: 10.1104/pp.113.234641

Confalonieri, M., Carelli, M., Tava, A., and Borrelli, L. (2019). Overexpression of MtTdp2 $\alpha$ (tyrosyl-DNA phosphodiesterase 2) gene confers salt tolerance in transgenic Medicago truncatula. Plant Cell Tiss. Organ Cult. 137, 157-172. doi: 10.1007/s11240-019-01560-3

Confalonieri, M., Faè, M., Balestrazzi, A., Mattia, D., Macovei, A., Valassi, A., et al. (2014). Enhanced osmotic stress tolerance in Medicago truncatula plants overexpressing the DNA repair gene MtTdp2 $\alpha$ (tyrosylDNA phosphodiesterase 2). Plant Cell Tiss. Organ Cult. 116, 187-203. doi: 10.1007/s11240-013-0395-y

Dahl, K. N., Kahn, S. M., Wilson, K. L., and Discher, D. E. (2004). The nuclear envelope lamina network has elasticity and a compressibility limit suggestive of a molecular shock absorber. J. Cell Sci. 117, 4779-4786. doi: 10.1242/jcs.01357

Davenport, S. B., Gallego, S. M., Benavides, M. P., and Tomaro, M. L. (2003). Behaviour of antioxidant defense system in the adaptive response to salt stress in Helianthus annuus L. cells. Plant Growth Regul. 40, 81-88.

Del Bene, F., Wehman, A. M., Link, B. A., and Baier, H. (2008). Regulation of neurogenesis by interkinetic nuclear migration through an apical-basal notch gradient. Cell 134, 1055-1065. doi: 10.1016/j.cell.2008.07.017

Duque, A. S., López-Gómez, M., Kráèmarová, J., Gomes, C. N., Araújo, S. S., Lluch, C., et al. (2016). Genetic engineering of polyamine metabolism changes Medicago truncatula responses to water deficit. Plant Cell Tiss. Organ Cult. 127, 681-690. doi: 10.1007/s11240-016-1107-1

Ehsanpour, A., and Fatahian, N. (2003). Effects of salt and proline on Medicago sativa callus. Plant Cell Tiss. Organ Cult. 73, 53-56.

Elmaghrabi, A. M., Ochatt, S., Rogers, H. J., and Francis, D. (2013). Enhanced tolerance to salinity following cellular acclimation to increasing $\mathrm{NaCl}$ levels in Medicago truncatula. Plant Cell Tiss. Organ Cult. 114, 61-70. doi: 10.1007/ s11240-013-0306-2

Elmaghrabi, A. M., and Ochatt, S. J. (2006). Isoenzymes and flow cytometry for the assessment of true-to-typeness of calluses and cell suspension of barrel medic prior to regeneration. Plant Cell Tiss. Organ Cult. 85, 31-43. doi: 10.1007/ s11240-005-9046-2

Elmaghrabi, A. M., Rogers, H. J., Francis, D., and Ochatt, S. J. (2017). PEG induces high expression of the cell cycle checkpoint gene WEE1 in embryogenic callus of Medicago truncatula: potential link between cell cycle checkpoint regulation and osmotic stress. Front. Plant Sci. 8:1479. doi: 10.3389/fpls.2017.01479

Folker, E. S., Östlund, C., Luxton, G. W., Worman, H. J., and Gundersen, G. G. (2011). Lamin A variants that cause striated muscle disease are defective in anchoring transmembrane actin-associated nuclear lines for nuclear movement. Proc. Natl. Acad. Sci. U.S.A. 108, 131-136. doi: 10.1073/ pnas. 1000824108

Gobert, A., Isayenkov, S., Voelker, C., Czempinski, K., and Maathuis, F. J. M. (2007). The two-pore channel TPK1 gene encodes the vacuolar K+ conductance and plays a role in $\mathrm{K}+$ homeostasis. Proc. Nat. Acad. Sci. U.S.A. 104, 10726-10731. doi: 10.1073/pnas.0702595104

Golkar, P., Amooshahi, F., and Arzani, A. (2017). The effects of salt stress on physio-biochemical traits, total phenolic and mucilage content of Plantago ovata Forsk under in vitro conditions. J. Appl. Bot. Food Qual. 90, 224-231.

Gundersen, G. G., and Worman, H. J. (2013). Nuclear positioning. Cell 152, 1376-1389. doi: 10.1016/j.cell.2013.02.031

Hideg, E., Jansen, M. A. K., and Strid, A. (2013). UV-B exposure, ROS, and stress: inseparable companions or loosely linked associates? Trends Plant Sci. 18, 107-115. doi: 10.1016/j.tplants.2012.09.003

Ingber, D. E. (2003). Tensegrity I. Cell structure and hierarchical systems biology. J. Cell Sci. 116, 1157-1173. doi: 10.1242/jcs.00359

Katsuhara, M., and Kawasaki, T. (1996). Salt stress induced nuclear and DNA degradation in meristematic cells of barley roots. Plant Cell Physiol. 37, 169-173. doi: 10.1093/oxfordjournals.pcp.a028928
Kranner, I., Minibayeva, F. V., Beckett, R. P., and Seal, C. E. (2010). What is stress? Concepts, definitions and applications in seed science. New Phytol. 188, 655-673. doi: 10.1111/j.1469-8137.2010.03461.x

Kurth, E., Cramer, G. R., Lauchli, A., and Epstein, E. (1986). Effects of NaCI and $\mathrm{CaCl} 2$ on cell enlargement and cell production in cotton roots. Plant Physiol. 82, 1102-1106. doi: 10.1104/pp.82.4.1102

Maniotis, A. J., Chen, C. S., and Ingber, D. E. (1997). Demonstration of mechanical connections between integrins, cytoskeletal filaments, and nucleoplasm that stabilize nuclear structure. Proc. Natl. Acad. Sci. U.S.A. 94, 849-854. doi: $10.1073 /$ pnas.94.3.849

Merchan, F., Breda, C., Hormaeche, J. P., Sousa, C., Kondorosi, A., Aguilar, O. M., et al. (2003). A Kruppel-like transcription factor gene is involved in salt stress responses in Medicago spp. Plant Soil 257, 1-9. doi: 10.1023/a:102625641 5556

Miki, Y., Hashiba, M., and Hisajima, S. (2001). Establishment of salt stress tolerant rice plant through set up $\mathrm{NaCl}$ treatment in vitro. Biol. Plant. 44, 391-395.

Munns, R., and Tester, M. (2008). Mechanisms of salinity tolerance. Annu. Rev. Plant Biol. 59, 651-681. doi: 10.1146/annurev.arplant.59.032607.092911

Murashige, T., and Skoog, F. (1962). A revised medium for rapid growth and bioassays with tobacco tissue cultures. Physiol. Plant 15, 473-497. doi: 10.1111/ j.1399-3054.1962.tb08052.x

Nagata, T., Nemoto, Y., and Hasezawa, S. (1992). Tobacco BY-2 cell-line as the Hela-cell in the biology of higher plants. Int. Rev. Cytol. 132, 1-30. doi: 10.1016/s0074-7696(08)62452-3

Naliwajski, M. R., and Skłodowska, M. (2014). The oxidative stress and antioxidant systems in cucumber cells during acclimation to salinity. Biol. Plant. 58, 47-54. doi: 10.1007/s10535-013-0378-1

Negrão, S., Schmöckel, S. M., and Tester, M. (2017). Evaluating physiological responses of plants to salinity stress. Ann. Bot. 119, 1-11. doi: 10.1093/aob/ mcw191

O’Brien, I. E. W., Baguley, B. C., Murray, B. G., Morris, B. A. M., and Ferguson, I. B. (1998). Early stages of the apoptotic pathway in plant cells are reversible. Plant J. 13, 803-814. doi: 10.1046/j.1365-313x.1998.00087.x

Ochatt, S. J. (2015). Agroecological impact of an in vitro biotechnology approach of embryo development and seed filling in legumes. Agron. Sust. Dev. 35, 535-552. doi: 10.1007/s13593-014-0276-8

Parida, A. K., and Das, A. B. (2005). Salt tolerance and salinity effects on plants: a review. Ecotoxicol. Env. Saf. 60, 324-349. doi: 10.1016/j.ecoenv.2004. 06.010

Quan, W., Liu, X., Wang, H., and Chan, Z. (2016). Physiological and transcriptional responses of contrasting alfalfa (Medicago sativa L.) varieties to salt stress. Plant Cell Tiss. Organ Cult. 126, 105-115. doi: 10.1007/s11240-016-0981-x

Werker, E., Lerner, H. R., Weimberg, R., and Poljakoff-Mayber, A. (1983). Structural changes occurring in nuclei of barley root cells in response to a combined effect of salinity and ageing. Am. J. Bot. 70, 222-225. doi: 10.1002/j. 1537-2197.1983.tb07862.x

Young, D. Y., and Udvardi, M. (2009). Translating Medicago truncatula genomics to crop legumes. Curr. Opin. Plant Biol. 12, 193-201. doi: 10.1016/j.pbi.2008.11. 005

Conflict of Interest Statement: The authors declare that the research was conducted in the absence of any commercial or financial relationships that could be construed as a potential conflict of interest.

Copyright (c) 2019 Elmaghrabi, Francis, Rogers and Ochatt. This is an open-access article distributed under the terms of the Creative Commons Attribution License (CC BY). The use, distribution or reproduction in other forums is permitted, provided the original author(s) and the copyright owner(s) are credited and that the original publication in this journal is cited, in accordance with accepted academic practice. No use, distribution or reproduction is permitted which does not comply with these terms. 